\title{
ASSESSMENT OF THE PROSPECTS FOR THE DEVELOPMENT AND EMPLOYMENT IN THE AREA OF GASTRONOMIC TOURISM IN THE RUSSIAN FAR EAST
}

\author{
Aleksandr Zubarev, Professor, Doctor of Economic Sciences ${ }^{1}$ \\ Elena Zubareva, Postgraduate ${ }^{2}$
}

DOI: https://doi.org/10.31410/tmt.2018.607

\begin{abstract}
The paper is dedicated to the problem of gastronomic tourism in the Far Eastern Federal District of Russia. As this tourism area is becoming increasingly popular around the world, its influence on the country's economy cannot be underestimated. The authors have attempted to evaluate the main directions for tourism development, building on the analysis of the current situation on the tourism market in Russia. The results of the study indicate that developing gastronomic tourism in the region should be based on organizing culinary events and festivals, in order to attract additional tourist attention to the Russian Far East.
\end{abstract}

Keywords: Gastronomic tourism, culinary tourism, Far Eastern Federal District, tourism development.

\section{INTRODUCTION}

$\mathrm{T}$

The economic situation in each country is largely determined by the state of each separately taken sector of its economy. Especially it concerns those sectors that have the largest share in the country's gross national product. Due to the ongoing processes of globalization and internationalization of countries' economies, tourism plays an increasingly important role - both in the international arena and within a country. Tourism can be considered, firstly, as a source of financial revenues to the state budget; secondly, as an efficient tool to increase the employment and the quality of life of the population; thirdly, as a basis for the social and cultural development and patriotism education; fourthly, as an effective educational tool and a means for the development of civil society [1].

Nevertheless, the quality of the national tourist product does not always meet the requirements and personal expectations of its potential consumers - Russian and foreign tourists. In addition, there are some other objective problems, such as: underdeveloped infrastructure, drawbacks in catering and hospitality industry, inefficient destination branding, etc.

In this regard, there is a need to find new ways to attract tourists to the regions of the Russian Federation by working on previously undeveloped spheres. Within this research, we focused on such a relatively new for Russian tourism industry area as gastronomic tourism. In many countries, it is not a new phenomenon; moreover, it is due to gastronomic tourism that have emerged the world-known brands of many regions of France, Italy, Spain and some other countries.

Modern Russia is yet at the beginning of its path as a destination for gastronomic tourism; however, the potential of the country in this area inspires optimism. Speaking about the Russian Far East, should be noted the richness and uniqueness of the regional natural resources, which can serve as the basis for formation of a quality tourist product.

\footnotetext{
$1 \quad$ Pacific National University, Khabarovsk, Russia

2 Pacific National University, Khabarovsk, Russia
} 


\section{CURRENT STATE OF GASTRONOMIC TOURISM: RUSSIAN AND FOREIGN EXPERIENCE}

Nowadays, the gastronomic tourism is an important component of the tourism industry in the world. As the tourism market is being saturated with various offerings from numerous tourism organizations, newly appeared unique tourist routes and non-standard tourist products, the tourists' needs and preferences change accordingly, becoming more complex and sophisticated. In recent years, the term "experience economy" becomes increasingly common both in publicist and scientific literature. This can be explained by the fact that a standard set of services no longer satisfies customers seeking to diversify their vacation with new emotions and experience. In this situation, the competition for the consumer of tourist services is exacerbated, and the gastronomic aspect of a trip becomes a significant competitive advantage for tourism organizations. Each region, hosting tourists, seeks to position itself as a unique tourist destination, to emphasize its cultural characteristics and identity. The gastronomy in this case plays an extremely important role, being one of the most vivid experiences for tourists and affecting directly the formation of the destination image.

The multinational composition of Russia is one of its characteristic features and a considerable competitive advantage of the country in the world market of tourist services. This cultural and national diversity contributes to a huge potential for the development of gastronomic tourism, both countrywide and at the city and regional level.

The relevance of the gastronomic tourism development can be also explained by the intensification of globalization processes in the world. Despite a number of obvious advantages, the phenomenon of globalization causes the need of self-identification and strengthening the sense of belonging to a particular social group. In this context, gastronomic tourism acts as an effective tool of social identification, and the local cuisine can be considered both as an anti-globalization phenomenon and one of the ways of understanding the world. There is a close link between a certain region and its characteristic food types, which is due to a number of factors: from climatic and geographical conditions to historically created culinary traditions. Thus, the consumption of local specialties allows people to feel their belonging to the particular social environment, and geographical diversity plays an important role in the tourism development of a country.

At the international level, the task of developing gastronomic tourism is carried out by a specially created organization, the World Food Travel Association [2]. The founder and executive director of the association, Erik Wolf, also known as the creator of the world gastronomic tourism industry, defines the gastronomic tourism as "the pursuit and enjoyment of unique and memorable food and drink experiences, both far and near". However, until 2012, another term, "culinary tourism", had been used to describe this industry. Later it was replaced with the term "gastronomic tourism" which is easier to understand and carries a less elitist connotation, according to a survey conducted among the English-speaking citizens.

The main objective of gastronomic tours is an acquaintance with the local food culture, the traditions and customs of the local population while discovering special features of the regional or national cuisine. Thus, according to the World Food Travel Association, this tourism area includes 12 elements [2]:

- culinary schools and workshops;

- culinary entertainment;

- culinary trends; 
- culinary events;

- culinary media;

- culinary preparations;

- gastronomic shops;

- gastronomic tours offered by tourism agencies;

- gastronomic establishments;

- farmer markets;

- gastronomic clubs;

- food production.

The growing importance of gastronomic tourism for Russia is evidenced by the establishment in 2015 of the Russian Gastronomic Tourism Association headed by Andrei Paramonov. The key objective of the association is to create suitable conditions for the sustainable development of gastronomic tourism in the country, to support small and medium-sized businesses in the hospitality industry and to increase the tourist attractiveness of Russian villages, cities and regions. According to the members of the Association, a high level of gastronomic tourism development can provide a number of advantages to the region, including: an increase in the number of tourists; growth in sales (accommodation, catering services, car rental, etc.); more extensive coverage in the media; the emergence of a new competitive advantage or unique trade offer (for example, unique food and drinks); increase in the volume of tax revenues to the budget; increased public awareness about tourism in the region; increased public pride and awareness of local gastronomy [2].

Local gastronomy is one of the factors determining the quality of a tourism destination. It should be noted that the role of local cuisine is to satisfy both the physiological and social needs of a person. According to UNWTO research [3], 88.2\% of the surveyed tourists consider gastronomy one of the key elements in the regional branding. For many travelers the intention to discover the local cuisine or even a certain regional specialty can serve as the main motivation for the trip, as well as the level of service in public catering establishments can be one of the criteria for the selection of property abroad.

The role of gastronomy in job creation, developing infrastructure of the region and preserving national traditions is also indisputable. This is evidenced the fact that UNESCO officially recognizes gastronomy as part of the historical and cultural heritage of humanity. For example, the national cuisine of France, Japan and Mexico are included in the UNESCO heritage list.

Nowadays, Europe is the undisputed leader in the field of gastronomic tourism. Especially popular are wine and gastronomic tours around the regions of France, Italy and Spain, whiskey tours to Scotland, fishing trips to Norway and the Netherlands, etc.

According to the data from the United States (2013) [4], during the gastronomic tour, the cost per person averaged 1,200 US dollars. About one-third of total expenses were spent directly on food and beverages. Each year, about 9 million people bought gastronomic tours around the United States, and the annual turnover of the market equaled 51 billion US dollars (about 12 billion dollars were food costs). According to statistics, the gastronomic tourists traveling in the US are generally well-educated people with a level of income above the average. They demonstrate a high interest in local culture and history and spread their knowledge in their home countries (the "word of mouth" effect). In America, Canada and Australia, active work is currently carried out in order to develop and implement different plans and strategies for the gastronomic tourism development on their territories. Remarkable is the fact that not only special consulting 
companies are involved in this work, but public organizations and local residents participate as well. The latter fully realize the importance of creation of the image of the area as an attractive tourist destination, and make a significant contribution to the regional tourism development.

In addition, it is worth paying attention to the experience of Wales (Great Britain) in the field of gastronomic tourism. By decision of the Welsh Government, a special action plan ("Food Tourism Action Plan for Wales") was developed in 2009 [5]. The document was aimed at the development of appropriate infrastructure in the region and included a number of important activities, such as:

- targeted development of the local gastronomic brands;

- organization of special events (gastronomic festivals, etc.);

- active involvement of local producers in the logistics chains of public catering establishments: restaurants, cafes, grocery stores, etc.;

- development of farm production;

- taking measures to improve the quality of service.

Using gastronomic aspect for developing regional tourism can be illustrated by the example of Spanish cuisine represented in [6].

Spanish cuisine is known internationally for various aspects such as its innovative nature or the high quality of the products used. Moreover, one of the most recognizable aspects of this gastronomy is the presentation made of the culinary product through the tapa concept which refers to a type of food presentation in small amounts, and it is usually shared among several people even using the same dish. Tapas are widely known throughout Spain, although in some regions they are known by another name, pintxos, for example, and they allow you to taste a small proportion of the typical gastronomic product of the area along with a drink. In certain geographical areas, the tapas that accompany the drink do not even involve an extra cost for the consumer. This small portion of food allows diners to try different types of culinary specialties and thus obtain a wide gastronomic experience. Thus, the typical culinary presentation that takes place in the city of Córdoba, based on the concept of "tapas" is one of the most valid options if you want to try many different dishes while sharing food with the rest of diners at a table, achieving in this way greater socialization. Tapas respond to one of the oldest traditions of Andalusia (and Spain), and today they are established both as heirs of the culinary tradition of this area and as an avant-garde trend by experimenting with new flavors in the cuisine. This allows an exportable model to other countries and, for this reason, in different cities around the world establishments are opening based on the concept of tapas.

Speaking about the development of gastronomic tourism in Russia (and, notably, in the Russian Far East), it must be recognized that, to date, the potential of the territory is not fully revealed yet. Meanwhile, there are a number of arguments in favor of active development of this area. Firstly, the inclusion of a gastronomic component in tourist routes will increase both the competitive potential of the regional cuisine and local gastronomic products, as well as the overall attractiveness of the territory. There is a strong connection between the territory and the gastronomy. This explains the uniqueness of the gastronomic tourism: while the ready-made culinary products can be exported outside the region, it is almost impossible to take the related traditions, resources and people's experience out of the territory.

Secondly, the economic effect from the development of gastronomic tourism consists in the diversification of the territory's economy. Using the gastronomic component brings tangible bene- 
fits to the various stakeholders: from the local population to small business owners in the field of hospitality and catering, local food producers, farmers, etc. Today, in many cities of the Far East (Khabarovsk, Vladivostok), there is a tendency to active promotion of the regional cuisine by local chefs, which can also be used as an incentive to develop gastronomic tourism in the territory.

Thirdly, the gastronomic tourism can play a particularly important role in the development of those regions that lack other recreational resources, such as climatic, geographical, cultural, historical, etc. Despite the access to the sea, the Far East cannot position itself as the sea holidays destination, as the average duration of the swimming season here is limited to two or three summer months (sometimes the beginning of September). However, the access to marine resources gives the region another, no less important advantage: the possibility of catching fresh seafood and using it in gastronomy.

\begin{tabular}{|c|c|c|c|c|c|c|c|c|c|c|c|c|}
\hline & \multicolumn{7}{|c|}{ International tourist arrivals (million) } & \multirow{2}{*}{$\begin{array}{c}\begin{array}{c}\text { Market } \\
\text { share } \\
(\%)\end{array} \\
2016^{*}\end{array}$} & \multicolumn{3}{|c|}{ Change (\%) } & \multirow{2}{*}{$\begin{array}{c}\begin{array}{c}\text { Aver- } \\
\text { age a } \\
\text { year } \\
(\%)\end{array} \\
2005- \\
2016^{*}\end{array}$} \\
\hline & 1990 & 1995 & 2000 & 2005 & 2010 & 2015 & $2016^{*}$ & & $14 / 13$ & $15 / 14$ & $16 * / 15$ & \\
\hline World: & 435 & 526 & 674 & 809 & 953 & 1189 & 1235 & 100 & 4,0 & 4,5 & 3,9 & 3,9 \\
\hline $\begin{array}{c}\text { Advanced econ- } \\
\text { omies }^{1}\end{array}$ & 299 & 337 & 424 & 470 & 516 & 654 & 685 & 55,5 & 5,7 & 5,0 & 4,8 & 3,5 \\
\hline $\begin{array}{c}\begin{array}{c}\text { Emerging econ- } \\
\text { omies }^{1}\end{array} \\
\end{array}$ & 136 & 189 & 250 & 339 & 437 & 536 & 550 & 44,5 & 2,1 & 4,0 & 2,7 & 4,5 \\
\hline \multicolumn{13}{|l|}{$\begin{array}{c}\text { By UNWTO } \\
\text { regions: }\end{array}$} \\
\hline Europe & 261,5 & 303,5 & 386,6 & 453,2 & 489,0 & 603,7 & 616,2 & 49,9 & 1,7 & 4,8 & 2,1 & 2,8 \\
\hline $\begin{array}{l}\text { Northern Eu- } \\
\text { rope }\end{array}$ & 28,7 & 36,4 & 44,8 & 59,9 & 62,8 & 75,4 & 80,2 & 6,5 & 5,3 & 6,5 & 6,4 & 2,7 \\
\hline Western Europe & 108,6 & 112,2 & 139,7 & 141,7 & 154,4 & 181,4 & 181,5 & 14,7 & 2,2 & 3,5 & 0,0 & 2,3 \\
\hline $\begin{array}{l}\text { Central / East- } \\
\text { ern Europe }\end{array}$ & 33,9 & 58,9 & 69,6 & 95,3 & 98,5 & 121,4 & 126,0 & 10,2 & $-9,1$ & 5,4 & 3,8 & 2,6 \\
\hline $\begin{array}{c}\text { Southern / } \\
\text { Medit. Europe }\end{array}$ & 90,3 & 96,0 & 132,6 & 156,4 & 173,3 & 225,5 & 228,5 & 18,5 & 6,9 & 4,9 & 1,3 & 3,5 \\
\hline $\begin{array}{c}\text { - of which EU- } \\
28 \\
\end{array}$ & 230,1 & 266,0 & 330,5 & 367,9 & 384,3 & 477,8 & 500,1 & 40,5 & 4,7 & 5,3 & 4,7 & 2,8 \\
\hline $\begin{array}{l}\text { Asia and the } \\
\text { Pacific }\end{array}$ & 55,9 & 82,1 & 110,4 & 154,1 & 208,1 & 284,0 & 308,4 & 25,0 & 6,1 & 5,4 & 8,6 & 6,5 \\
\hline North-East Asia & 26,4 & 41,3 & 58,3 & 85,9 & 111,5 & 142,1 & 154,3 & 12,5 & 7,3 & 4,3 & 8,6 & 5,5 \\
\hline South-East Asia & 21,2 & 28,5 & 36,3 & 49,0 & 70,5 & 104,2 & 113,2 & 9,2 & 2,9 & 7,4 & 8,6 & 7,9 \\
\hline Oceania & 5,2 & 8,1 & 9,6 & 10,9 & 11,4 & 14,3 & 15,6 & 1,3 & 6,1 & 7,6 & 9,4 & 3,3 \\
\hline South Asia & 3,2 & 4,2 & 6,1 & 8,3 & 14,7 & 23,4 & 25,3 & 2,0 & 12,9 & 2,3 & 7,8 & 10,7 \\
\hline Americas & 92,8 & 108,9 & 128,2 & 133,3 & 150,1 & 150,1 & 199,3 & 16,1 & 8,5 & 5,9 & 3,5 & 3,7 \\
\hline North America & 71,8 & 80,5 & 91,5 & 89,9 & 99,5 & 127,5 & 130,5 & 10,6 & 9,7 & 5,5 & 2,4 & 3,4 \\
\hline Caribbean & 11,4 & 14,0 & 17,1 & 18,8 & 19,5 & 24,1 & 25,2 & 2,0 & 5,5 & 8,1 & 4,7 & 2,7 \\
\hline $\begin{array}{c}\text { Central Amer- } \\
\text { ica }\end{array}$ & 1,9 & 2,6 & 4,3 & 6,3 & 7,8 & 10,2 & 10,7 & 0,9 & 5,6 & 6,8 & 4,9 & 5,0 \\
\hline South America & 7,7 & 11,7 & 15,3 & 18,3 & 23,2 & 30,8 & 32,8 & 2,7 & 7,1 & 5,9 & 6,6 & 5,4 \\
\hline Africa & 14,8 & 18,7 & 26,2 & 34,8 & 50,4 & 53,4 & 57,8 & 4,7 & 0,6 & $-2,9$ & 8,1 & 4,7 \\
\hline North Africa & 8,4 & 7,3 & 10,2 & 13,9 & 19,7 & 18,0 & 18,6 & 1,5 & $-1,4$ & $-12,0$ & 3,5 & 2,7 \\
\hline $\begin{array}{c}\text { Sub-Saharan } \\
\text { Africa }\end{array}$ & 6,4 & 11,5 & 16,0 & 20,9 & 30,7 & 35,4 & 39,2 & 3,2 & 1,9 & 2,4 & 10,5 & 5,9 \\
\hline Middle East & 9,6 & 12,7 & 22,4 & 33,7 & 55,4 & 55,6 & 53,6 & 4,3 & 8,7 & 0,6 & $-3,7$ & 4,3 \\
\hline
\end{tabular}

Table 1: International tourist arrivals 
Fourthly, the inclusion of gastronomic aspect to the strategy for development of regional tourism can compensate, in one way or another, the negative effect of the global trends towards globalization and unification, emphasizing the cultural identity and uniqueness of a particular territory. At the same time, from the ecological point of view, the development of gastronomic tourism on the territory allows minimizing the negative impact on the environment, since it reduces the need to transport gastronomic products outside the region.

According to the head of the Russian Federal Agency for Tourism Oleg Safonov, the significance of the Far Eastern Federal District for the Russian tourism industry cannot be overestimated, since "it is not only a territory with a unique natural, historical and cultural diversity, but also a region that borders on countries with leading dynamics of growth of tourist flows". The Far Eastern Federal District occupies 36\% of the territory of the country and possesses huge natural, recreational and gastronomical resources. According to the official data of the World Tourism Organization report (UNWTO Tourism Highlights: 2017 Edition), the countries of the Asia-Pacific region in 2016 showed the highest growth rates in the number of international tourist arrivals (9\%) [3]. In view of the fact that nowadays the Asia-Pacific region demonstrates particularly high rates of growth in tourist flows, the tourism development on the Far East is an especially relevant task. The table 1 demonstrates the data of the World Tourism Organization (UNWTO) on tourist arrivals to different regions of the world during several years. That will help to draw conclusions about the changes in tourist flows and to identify the most promising tourist destinations.

As the table shows, the average annual growth rate of the number of tourist arrivals to the Asia-Pacific region for the period from 2005 to 2016 exceeds the similar indicator in other regions of the world (6.5\% against the world average of $3.9 \%)$.

\section{DEVELOPING GASTRONOMIC TOURISM IN THE RUSSIAN FAR EAST}

In recent years, there has been a positive dynamics of the domestic and inbound tourism development in the Russian Far East that is evidenced by the following figures: in 2015, 2.7 million Russian tourists visited the Far Eastern region, and in 2016, this indicator reached 3.5 million (in other words, it increased almost by 30\%) [7]. The tourist flow to Kamchatka has increased threefold for the last three years. Prospective is the development of cruise tourism in the region: about two million cruise tourists every year pass Russian borders while travelling from the Asia-Pacific region to Alaska. Also, according to the head of the Russian Federal Agency for Tourism, at the moment, the project of a so-called "Eastern Ring of Russia" (by analogy with the Golden Ring of Russia) is being developed. Its main objective is to give the chance to arriving tourists to discover at once several regions of the Far East.

It is also worth paying attention to the increased interest in Russia by tourists from China and South Korea. Thus, the tourist flow from South Korea increased by $42 \%$ in the first half of 2017. And the number of tourists from China increased by 15\% over last year. One of the reasons for such growth is a simplification of visa regime (electronic visa to Russia) allowing tourists to get a visa online [7].

The primary objectives in the development of tourism in the Far East are the improvement of the tourist infrastructure in the region and the creation of new accommodation facilities. Moreover, 
Safonov highlighted the need to improve tourist services quality and to promote more actively Russian tourist products in the market of China, South Korea and Japan.

Among the advantages of the Far Eastern region which attract tourists from the Asia-Pacific countries, we can particularly highlight the following: the region's availability for tourists, the diversity of ecological tourist routes, a wide variety of excursion programs, and also becoming more and more popular gastronomic tours. Both Russian and foreign tourists travel not only for cultural, but also for culinary experience: for many of them the opportunity to discover local delicacies (such as seafood, wild game specialties, wild plants, mushrooms, etc.) is a key motivation for the trip. Today, the gastronomic tours to the region are organized by the Russian Export Center, the Federal Agency for Tourism and the Ministry of Agriculture of the Russian Federation. The first gastronomic tours are planned to be held in Khabarovsk, Vladivostok and some other cities of the Far East.

Gastronomic tourism is considered one of the priority directions in the development of domestic and inbound tourism in the Far East of Russia. In this context, the regional cuisine can be seen as an instrument of so-called "soft diplomacy", which means a way to bring to the tourist the values of the territory through the local gastronomic specialties which reflect its specificity and uniqueness. The main prerequisite for the gastronomic tourism development in the region is the diversity of national cuisines of the local inhabitants, as well as considerable natural resources of the Far East. The regional gastronomy is represented by the following types of national cuisine [8]:

1. Cuisine of the indigenous people of the Far East (the Nanais, Evenks, Udege, Chukchi, etc.);

2. Traditional Russian and Ukrainian cuisine, adapted for local products;

3. Chinese, Korean, Japanese, Thai, Vietnamese, Uzbek and other types of national cuisine, borrowed from other countries;

4. Local home cooking of the Soviet and post-Soviet period.

Thus, the Far Eastern cuisine is a mix of different gastronomic trends, adapted for the modern consumer (considering the resources available in the region).

Talking about tourism development in the region, we cannot ignore the fact that the population of the Russian Far East is highly diversified in terms of people's nationality, which is partly due to active migration process. Migration has a strong impact on cultural (and, thus, gastronomical) condition of the regional. The influence of the Asian cultures, brought by immigrants, finds expression in opening new cafes and restaurants of foreign cuisine.

For example, in Khabarovsk there is a number of cafes and restaurants of Armenian, Ukrainian, and Uzbek cuisine. Interestingly enough, many tourists from the neighboring countries (such as China, Japan and South Korea) are attracted by the opportunity to taste the local specialties of these countries. Thus, the migration processes may also contribute to the development of the gastronomic tourism in the region.

To quote Russian political observer Valery Vyzhutovich, labor migrants are actively integrated into the Russian economy, because there is objective need for additional manpower in our country. According to the International Organization for Migration [9], the largest share is taken by 
immigrants from Uzbekistan (25\%), Tajikistan (16\%), Ukraine (11\%), Kyrgyzstan (7.5\%), and Moldova (5.5 \%). During 2016-2017, their total number is around 2 million people.

In 2017, around 400 thousand foreign citizens have been put on the migration registration in the Russian Far East (which is $15 \%$ more than in the previous year). More than a half of them have arrived for the purpose of work.

Due to the geographical position of our region, the main workforce "provider" for the Far East of Russia has always been the People's Republic of China. Around $70 \%$ of all coming foreigners are Chinese citizens. However, today the number of citizens coming to the Russian Far East from the CIS countries is steadily growing. According to data for 2014, the largest share is taken by citizens of Uzbekistan (80 700 people, or $28 \%$ ), Kyrgyzstan (36 400 people, which is more than $12 \%$ ), Ukraine (3 700, or 11\%), Armenia (18 900, or 6.5\%), and Tajikistan (18 200, or 6\%) [9].

Here is some statistical data characterizing the condition of the tourism sector in the Far Eastern Federal District (figures 1-3).

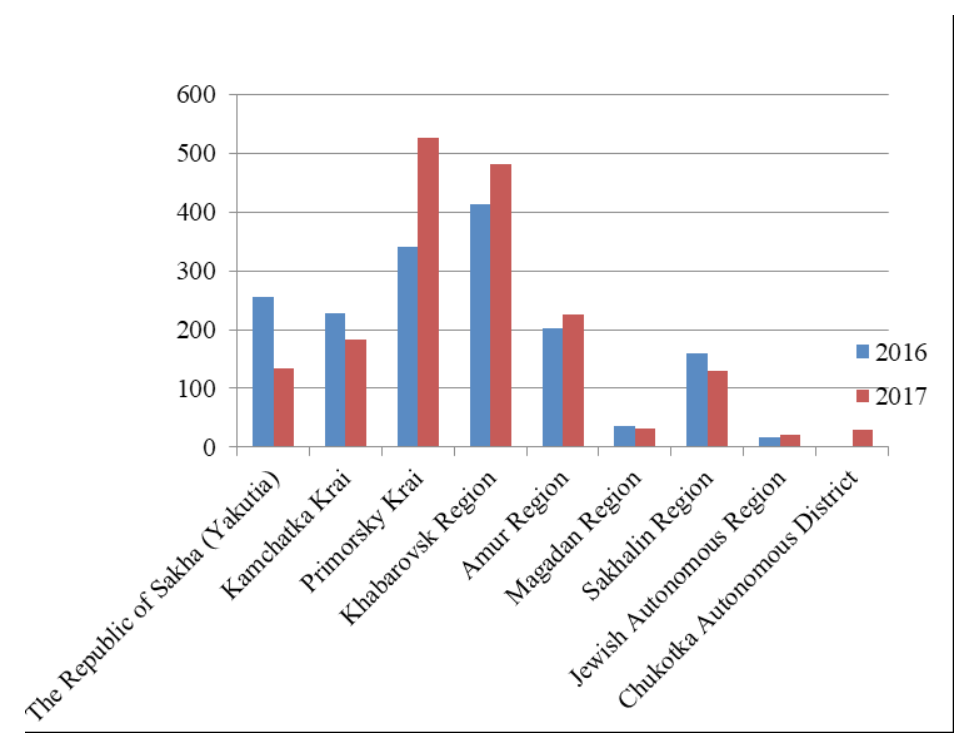

Figure 1: The average number of employees of travel companies in the Far Eastern Federal District (excluding external part-time workers), people

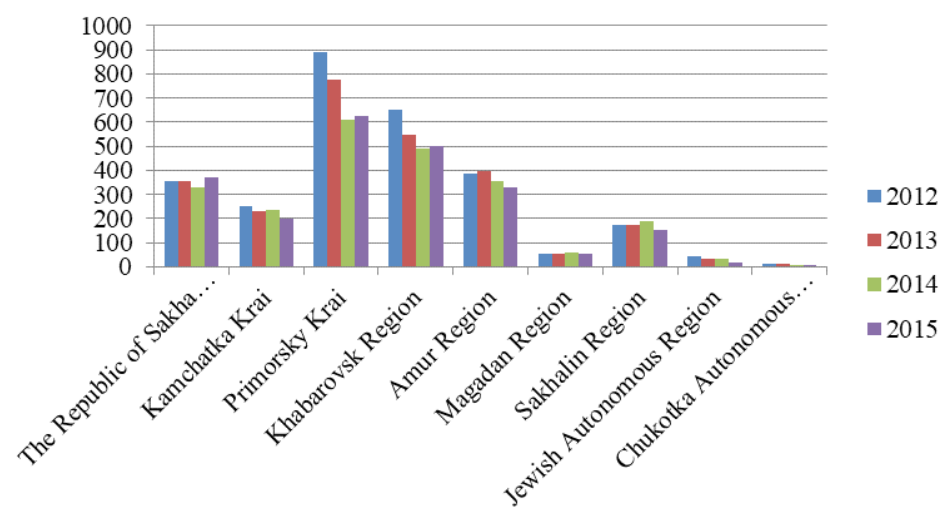

Figure 2: The average number of employees of travel companies in the Far Eastern Federal District (including external part-time workers), people 


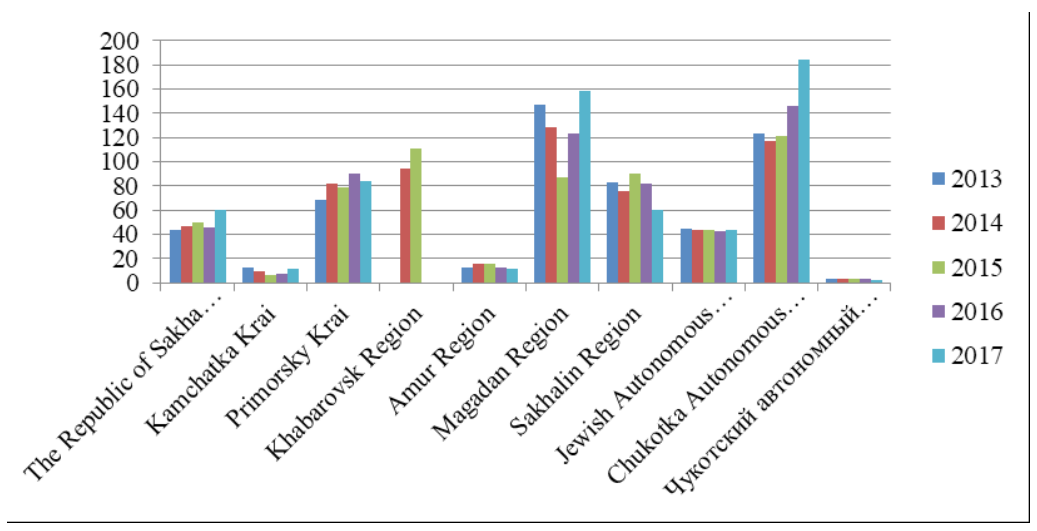

Figure 3: Number of tourism companies in the Far Eastern Federal District

In order to objectively assess the current state and the potential of gastronomic tourism in the Far East, the collection of data on catering enterprises in the seven largest cities of the Far Eastern Federal District was conducted. The survey covered the cities of Khabarovsk, Vladivostok, Yakutsk, Komsomolsk-On-Amur, Blagoveshchensk, Yuzhno-Sakhalinsk and Petropavlovsk-Kamchatsky (table 2) [10]. Data on the population (as of January 1, 2017) are presented in the table 3 [11].

\begin{tabular}{|c|c|c|c|c|c|c|c|}
\hline National cuisine & Khabarovsk & Vladivostok & Yakutsk & $\begin{array}{c}\text { Komsomolsk } \\
\text {-on-Amur }\end{array}$ & $\begin{array}{l}\text { Blagove- } \\
\text { shchensk }\end{array}$ & $\begin{array}{c}\text { Yuzh- } \\
\text { no-Sakhal- } \\
\text { insk } \\
\end{array}$ & $\begin{array}{c}\text { Petropav- } \\
\text { lovsk- } \\
\text { Kamchatsky }\end{array}$ \\
\hline Australian & - & 1 & - & - & - & - & - \\
\hline Author's meals & - & 13 & 1 & - & 1 & 4 & - \\
\hline Azerbaijan & 18 & 16 & 1 & 8 & 8 & 3 & 12 \\
\hline Asian & 3 & 13 & 7 & 2 & 2 & 6 & 2 \\
\hline American & 28 & 31 & 29 & 9 & 3 & 34 & 3 \\
\hline English & 1 & 2 & - & - & - & 1 & - \\
\hline Arabic & 2 & - & 1 & - & - & 5 & - \\
\hline Armenian & 12 & 41 & 3 & 4 & 15 & 1 & - \\
\hline African & - & - & - & 1 & - & - & - \\
\hline Bavarian & - & - & - & - & - & 1 & - \\
\hline Belarusian & 1 & - & - & - & - & - & - \\
\hline Belgian & - & 1 & - & 1 & - & - & - \\
\hline Bulgarian & 1 & - & - & - & - & - & - \\
\hline Buryat & 1 & 3 & 7 & - & 2 & - & - \\
\hline Hungarian & 1 & - & - & - & - & - & - \\
\hline Eastern & 20 & 29 & 26 & 6 & 2 & 62 & 13 \\
\hline Vietnamese & - & 2 & 1 & - & - & - & - \\
\hline Hawaiian & - & 1 & 1 & - & - & - & - \\
\hline Greek & 3 & 2 & - & - & - & - & 1 \\
\hline Georgian & 10 & 17 & 5 & 2 & 3 & 8 & 1 \\
\hline Home cooking & 3 & 3 & 9 & - & - & - & 2 \\
\hline Jewish & 3 & 14 & - & - & - & - & 1 \\
\hline European & 205 & 314 & 102 & 60 & 58 & 157 & 65 \\
\hline Indian & 1 & 4 & 1 & - & - & 3 & - \\
\hline International & 2 & 1 & - & - & - & - & - \\
\hline Irish & - & 2 & - & - & 1 & 1 & 1 \\
\hline Spanish & 2 & - & - & - & - & - & - \\
\hline Italian & 49 & 56 & 24 & 16 & 9 & 30 & 11 \\
\hline Caucasian & 33 & 41 & 10 & 10 & 2 & 6 & 5 \\
\hline Kazakh & - & 1 & - & - & - & 1 & - \\
\hline Chinese & 64 & 90 & 15 & 34 & 59 & 5 & 5 \\
\hline Korean & 21 & 30 & 7 & 4 & 2 & 45 & 3 \\
\hline Mexican & 6 & 7 & 1 & 4 & 1 & 5 & 1 \\
\hline
\end{tabular}




\begin{tabular}{|l|c|c|c|c|c|c|c|}
\hline Mongolian & - & 1 & 3 & - & 1 & - & - \\
\hline Northern & - & - & - & - & - & - & 1 \\
\hline German & 8 & 3 & - & - & - & - & 1 \\
\hline Ossetian & 2 & 2 & 1 & - & 1 & 2 & 1 \\
\hline Pan-Asian & - & 26 & 14 & 1 & - & 4 & 6 \\
\hline Russian & $\mathbf{1 0 1}$ & $\mathbf{1 8 5}$ & $\mathbf{6 4}$ & $\mathbf{5 1}$ & $\mathbf{5 6}$ & $\mathbf{4 7}$ & $\mathbf{3 6}$ \\
\hline Fish meals & - & 4 & - & - & - & - & 2 \\
\hline Singaporean & - & 5 & - & - & - & - & - \\
\hline Mediterranean & - & 4 & 2 & - & - & 5 & - \\
\hline Steak house & 2 & 3 & 2 & 10 & - & - & - \\
\hline Tajik & 1 & - & - & - & - & - & 1 \\
\hline Thai & 2 & 4 & 5 & - & 3 & 1 & 1 \\
\hline Tatar & - & - & 1 & 1 & - & 1 & - \\
\hline Turkish & 5 & 1 & 2 & 3 & - & 3 & 1 \\
\hline Uzbek & $\mathbf{3 5}$ & $\mathbf{3 0}$ & $\mathbf{1 3}$ & $\mathbf{6}$ & $\mathbf{1 0}$ & $\mathbf{4}$ & $\mathbf{1 0}$ \\
\hline Uighur & - & 1 & 2 & - & - & 1 & - \\
\hline Ukrainian & 3 & 8 & 7 & 1 & 1 & 1 & - \\
\hline Finnish & 1 & - & - & - & - & 2 & 1 \\
\hline French & 2 & 5 & - & - & - & & 1 \\
\hline Fusion & 3 & 4 & 1 & 1 & - & - & - \\
\hline Czech & - & 1 & - & - & 2 & & - \\
\hline Yakut & $\mathbf{4 8}$ & $\mathbf{5 5}$ & 46 & - & - & - & - \\
\hline Japanese & $\mathbf{5 8 0}$ & $\mathbf{4 0 5}$ & $\mathbf{2 2 9}$ & $\mathbf{3 4 4}$ & $\mathbf{4 3 1}$ & $\mathbf{2 2 3}$ \\
\hline Total & & & & & & \\
\hline
\end{tabular}

Table 2: Number of catering establishments in the largest cities of the Far East by types of national cuisine

\begin{tabular}{|l|c|}
\hline City & Population \\
\hline Khabarovsk & 616242 \\
\hline Vladivostok & 606589 \\
\hline Yakutsk & 307911 \\
\hline Komsomolsk-on-Amur & 249810 \\
\hline Blagoveshchensk & 224419 \\
\hline Yuzhno-Sakhalinsk & 194882 \\
\hline Petropavlovsk-Kamchatsky & 180454 \\
\hline
\end{tabular}

Table 3: The population of the Russian Federation for municipalities as of January 1, 2017

Thus, the national cuisine presented in the restaurants of the Russian Far East is very diverse, which is an undoubted competitive advantage of the region in the field of tourism services. Local catering establishments are oriented both on Russian and foreign clients, which contributes to the formation of the image of the Russian Far East as an attractive tourist destination.

Obviously, for successful development of the urban gastronomic tourism in the cities of the Far East, it is necessary to develop the public catering segment, to open new restaurants specializing in the traditional Far Eastern cuisine, as well as to rebrand existing catering outlets (for example, by including in the menu gastronomic specialties which are specific for this particular region). In addition, special attention should be given to the quality of service, since this factor (along with the food quality) often plays a determining role in attracting customers.

Speaking about tourism development in the region, it is important to consider availability of hotels and similar accommodation facilities for tourists (tables 4 and 5) [10]. 


\begin{tabular}{|c|c|c|c|c|c|c|c|}
\hline Stars & $\begin{array}{c}\text { Khaba- } \\
\text { rovsk }\end{array}$ & $\begin{array}{c}\text { Vladiv- } \\
\text { ostok }\end{array}$ & Yakutsk & $\begin{array}{c}\text { Komso- } \\
\text { molsk } \\
\text {-on-Amur }\end{array}$ & $\begin{array}{c}\text { Blagove- } \\
\text { shchensk }\end{array}$ & $\begin{array}{c}\text { Yuzh- } \\
\text { no-Sakhal- } \\
\text { insk }\end{array}$ & $\begin{array}{c}\text { Petro- } \\
\text { pavlovsk } \\
- \text {-Kamchat- } \\
\text { sky }\end{array}$ \\
\hline $1^{*}$ & - & 1 & - & - & - & 2 & - \\
\hline $2^{*}$ & 10 & 10 & 3 & 1 & 3 & 2 & 2 \\
\hline $3^{*}$ & 25 & 25 & 3 & 7 & 12 & 13 & 2 \\
\hline $4^{*}$ & 5 & 3 & 3 & - & 1 & 3 & 1 \\
\hline $5^{*}$ & 2 & 2 & - & - & - & - & - \\
\hline Total & $\mathbf{9 8}$ & $\mathbf{1 5 1}$ & $\mathbf{1 1 0}$ & $\mathbf{2 8}$ & $\mathbf{6 1}$ & $\mathbf{4 5}$ & $\mathbf{3 0}$ \\
\hline
\end{tabular}

Table 4: Number of hotels and similar accommodation facilities in the largest cities of the Far Eastern Federal District

\begin{tabular}{|c|c|c|c|c|c|c|}
\hline Khabarovsk & Vladivostok & Yakutsk & $\begin{array}{c}\text { Komsomolsk } \\
\text {-on-Amur }\end{array}$ & $\begin{array}{c}\text { Blagove- } \\
\text { shchensk }\end{array}$ & $\begin{array}{c}\text { Yuzh- } \\
\text { no-Sakhal- } \\
\text { insk }\end{array}$ & $\begin{array}{c}\text { Petro- } \\
\text { pavlovsk } \\
\text {-Kamchatsky }\end{array}$ \\
\hline 15,91 & 24,89 & 35,72 & 11,21 & 27,18 & 23,09 & 16,62 \\
\hline
\end{tabular}

Table 5: The number of hotels and similar accommodation facilities per 100 thousand people

As can be seen from the table 5, hotels and other accommodation facilities in the largest cities of the Far East are extremely unevenly distributed. The highest rate is demonstrated in Vladivostok, Yakutsk and Khabarovsk, then Blagoveshchensk, Yuzhno-Sakhalinsk, Petropavlovsk-Kamchatsky and, finally, Komsomolsk-On-Amur. Comparing the cities by the relative indicator (the number of hotels per 100 thousand people), the leader is Yakutsk, followed by Blagoveshchensk, Vladivostok and Yuzhno-Sakhalinsk. In Khabarovsk, there are less than 16 hotels for every 100 thousand people. Thus, it can be concluded that the largest cities of the Far East have insufficient number of hotels and similar accommodation facilities, which negatively affects the image of the region as a tourist destination.

To date, various events, dedicated to local gastronomy and the national culture of the indigenous people of the Far East, are gaining popularity. Both in the cities and in small villages, different gastronomic festivals, culinary exhibitions, national holidays and other events are held in framework of gastronomic and event tourism. Some of these events are presented in the table 6.

Thus, the existing gastronomic potential of the regions of the Far East, in our opinion, can serve as a necessary and sufficient basis for the development of tourism both in the administrative centers of the regions and in the smaller settlements of the Far East, subject to sound strategic planning and effective management.

Gastronomic tourism as a separate line of regional tourism is closely related to the so-called event tourism, which is another popular area of tourism nowadays. The features and problems of event tourism are considered by many Russian and foreign researchers. Event tourism includes creating and organizing different festivals, conventions, meetings and other large-scale events.

Visiting gastronomic events can be attributed both to gastronomic and event tourism. Thus, both these directions should be considered as perspective options for the tourism development in the Far Eastern Federal District (along with nature, sports, medical and some other types of regional tourism). Consequently, there is a need to develop the relevant elements of the tourism infrastructure in the region, including improvement of air and rail communication in the Far East, construction of new hotels, catering establishments and sites for mass events, and urban improvement in general. 


\begin{tabular}{|c|c|}
\hline $\begin{array}{l}\text { Khabarovsk } \\
\text { Territory }\end{array}$ & $\begin{array}{l}\text { International Gastronomic Forum (Khabarovsk, September 25-27, 2017) } \\
\text { Festival-competition "Silver Smelt" (Sovetskaya Gavan, March 24, 2018) } \\
\text { Exhibition "DahlPischeProm-2018" (Khabarovsk, April 5, 2018) } \\
\text { Gastronomic Festival "Barbecue Battle" (Khabarovsk, June 5, 2018) } \\
\text { Exhibition and trade fair "Our choice 27" (Khabarovsk, June 10-11, 2018) }\end{array}$ \\
\hline Primorsky Krai & $\begin{array}{l}\text { Gastronomic Festival of Navaga (Vladivostok, Nakhodka, February 15-25, 2018) } \\
\text { Pancake Festival (Vladivostok, February 18, 2018) } \\
\text { Mussel Festival (Vladivostok, May 11-20, 2018) } \\
\text { Strawberry Festival (Spassk-Dalny, June 23, 2018) } \\
\text { Scallop Festival (Vladivostok, the first half of July) } \\
\text { Folklore Festival "Honey Spas" (Kavalerovo village, August 14, 2018) } \\
\text { Harvest Festival (Shtykovo village, August 18, 2018) } \\
\text { Honey Festival (Luchegorsk, mid-August) } \\
\text { Honey Festival (Anuchino village, end of August) } \\
\text { Crab Festival (Vladivostok, September 17-27, 2018) } \\
\text { Taiga Festival (Vladivostok, September 29- October 14, 2018) } \\
\text { Street Food Festival "Lavash" (Vladivostok, mid-August) } \\
\text { Gastronomic Festival "Try the Taste of Tottori" (Vladivostok, February) } \\
\text { Culinary delights at the "Street of the Far East" (Vladivostok, Russian Island) } \\
\text { Fish Festival "Sagdi Dava" (Vladivostok, September) } \\
\text { Festival of Korean cuisine, culture and tourism (Vladivostok, mid-October) } \\
\text { Gastronomic Festival "Days of Udege cuisine" (Bikin National Park, beginning } \\
\text { of November) } \\
\text { Winter Fish Festival (Vladivostok, Nakhodka, December 5-15, 2018) }\end{array}$ \\
\hline Amur Region & $\begin{array}{l}\text { Ethnic tour with the participation of tourists in the national holiday "Reindeer } \\
\text { herder's Day", acquaintance with the national cuisine and life of the indigenous } \\
\text { inhabitants of the village - the Evenks (Ivanovskoe village, end of March 2018) }\end{array}$ \\
\hline $\begin{array}{l}\text { The Republic of } \\
\text { Sakha (Yakutia) }\end{array}$ & Gastronomic Festival “Taste of Yakutia” (November 30 - December 2) \\
\hline Sakhalin Region & $\begin{array}{l}\text { Gastronomic Festival "Fish Island “ (Yuzhno-Sakhalinsk, September 6 - 10, } \\
\text { 2017) }\end{array}$ \\
\hline Kamchatka Krai & Day of the first fish (first Sunday in June) \\
\hline
\end{tabular}

Table 6: Gastronomic events in the Far East

Within the development of gastronomic tourism in the Far Eastern Federal District, it seems advisable to focus on the following areas:

- organization of special gastronomic and wine tours by local travel agencies;

- establishing culinary centers and schools, conducting culinary classes and workshops; wine courses and sommelier schools; professional training in the area of public catering;

- self-visit to local restaurants with regional and/or national cuisine;

- organization of excursions to the objects of industrial objects of gastronomic tourism (for example, to the factories, confectionaries, shops, creameries, etc.);

- organized visits to farms and farmers' markets with environmentally friendly products;

- visits to special gastronomic shops, fairs, exhibitions and local products tastings;

- organization of wine and gastronomic festivals, celebrations, competitions and other similar events;

- development of culinary media: television programs devoted to cooking, culinary shows, etc. 
The implementation of each of the abovementioned areas requires an individual approach and substantial financial investments; it involves the participation of both federal and municipal authorities and representatives of small and medium-sized businesses.

In our opinion, one of the most prospective strategic lines in the development of the tourism industry is the organization of various events (different exhibitions, forums, conferences, seminars, meetings, visits of delegations, business missions, international meetings, etc.), which are dedicated to the topical issues and problems of gastronomic tourism in the Far East. Organization of such mass events can attract interest to the regions of the Far Eastern Federal District both among the tourists and potential investors. For example, the Olympic Games in Sochi have helped to increase the turnover of the catering industry in Russia by $0.4 \%$ and have brought huge additional profit ( 5 billion rubles) to the restaurants of the city. Despite the fact that organizing events of this scale in the Far East is not planned in the nearest future, these figures clearly illustrate the positive effect of mass events on the industry development. However, this effect is rather short-term. In order to achieve a lasting effect, it is necessary to hold gastronomic events in the region on a regular basis, which will ensure a constant flow of tourists to the region.

According to the experts of the Tourist Information Center of Primorsky Krai [12], recently there has been a tendency to combine business and cultural tourism programs. A vivid example of such a combination is the East Economic Forum which successfully hosts the Far East Street exhibition. Such events allow their guests not only to establish new business contacts and solve business issues, but also to relax and get acquainted with the region and its culture.

It is advisable to conduct such events not only in the largest cities of the Far Eastern Federal District, but also in the less populated settlements. Such an approach will ensure an even distribution of tourist flows across the Far Eastern regions, as well as a better use of available resources. In addition, it is also necessary to work with the local population, since the image and general attractiveness of the destination for potential tourists largely depends on how ready local residents are to receive tourists on their territory.

In many developed countries (for example, France), it is a common practice to:

- promote the cultural heritage and local gastronomy through the social networks, Internet and in the press;

- accompany foreign visitors and presenting typical sights to them;

- provide legal and administrative assistance;

- provide assistance in language learning;

- organize discussions, meetings and debates on the topic of regional tourism development and prospects;

- organize exhibitions, debates and other national and international events;

- develop international cultural exchanges.

Organizing the abovementioned activities on a regular basis greatly contributes to the promotion of regional cuisine and helps to strengthen the brand of a destination in general. This experience should be taken into account when designing development strategies in the regions of Russian Federation. In our opinion, the government should support financially and legally the initiative of local tourism organizations in the field of gastronomic tourism, as this is one of the perspective directions for tourism development in the Russian Far East. Today, the Far Eastern region of Russia has a great potential (speaking of natural resources, cultural heritage, locally produced foods and beverages), but this potential is not used properly. Creating organizations 
and associations specializing in food tourism will boost the development of the tourism industry as a whole due to attracting both Russian and foreign visitors.

Thus, the development of gastronomic tourism in the Far East should be based not only on the development of catering sphere and activities of tourism organization, but also on the organization of the activities in the context of event tourism. Such a comprehensive approach, firstly, will help to attract the maximum number of foreign tourists to the region, and secondly, will promote the territory brand, which is especially important in the current situation on the tourism market in the Far East.

\section{REFERENCES}

[1] Reference system "Consultant Plus" (official website). URL: http://www.consultant.ru/ sys/english/.

[2] World Food Travel Association (official website). URL: http://агтр.pф.

[3] UNWTO Tourism Highlights: 2017 Edition. URL: https://www.e-unwto.org/doi/ pdf/10.18111/9789284419029.

[4] Zheltov, A. V. (2013) Gastronomicheskyi turism: kak eto delayut u nih. URL: http://vkusnozhit.com/articles/gastronomicheskiy-turizm-kak-eto-delayu-0.

[5] The Food Tourism Action Plan for Wales 2015 - 2020. URL: https://businesswales.gov. wales/sites/business-wales/files/tourism/Food-Tourism-Action-Plan-2015-2020\%20 -150310-EN.pdf.

[6] Jiménez-Beltrán, F. J., López-Guzmán, T., González Santa Cruz, F. (2016) Analysis of the Relationship between Tourism and Food Culture, Córdoba, Spain, pp. 1-2.

[7] RIA Novosti (official website). Turisticheskoe znachenie DFO nel'zya pereocenit', schitayut v Rosturisme (2017). URL: https://ria.ru/tourism/20170907/1502015594.html.

[8] Development program for the Russian Far Eastern regional cuisine (2017), Pacific Russia Food. URL: http://prta.pro/files/pacific-russia-food-concept.pdf.

[9] Valery Vyzhutovich (2017) Napravlenie - Dal'nyi Vostok, Rossyiskaya Gazeta (official website). URL: https://rg.ru/amp/2017/11/23/reg-dfo/valerij-vyzhutovich-trudovye-migranty-integrirovany-v-rossijskuiu-ekonomiku.html.

[10] 2GIS digital maps (official website). URL: https://2gis.ru/.

[11] Federal State Statistics Service (official website). URL: http://www.gks.ru/.

[12] Tourist Information Center of Primorsky Krai (official website). URL: http://www.primorsky.ru/news/140703/. 